\title{
THE UNITED STATES AND TURKEY'S MEMBERSHIP IN THE EUROPEAN UNION
}

\author{
SABRI SAYARI
}

\begin{abstract}
Washington's support for Ankara on the issue of Turkish membership in the EU became part of the agenda of U.S.-Turkish bilateral relations in the late 1980s. However, it was during the course of the next decade that American officials began to engage in intensive lobbying efforts among key U.S. allies in Europe to promote Turkey's EU aspirations. This article is analyzing the motives behind the US support for Turkey's bid for membership in the EU and the differences in the approaches between the US and the EU on this issue.
\end{abstract}

\section{KEYWORDS}

EU, Turkish-US relations, Turkish-EU relations, Turkish foreign policy, US Foreign Policy, EU-US relations. 


\section{The U.S. and EU-Turkey Relations}

Washington's support for Ankara on the issue of Turkish membership in the EU became part of the agenda of U.S.-Turkish bilateral relations in the late 1980s. However, it was during the course of the next decade that American officials began to engage in intensive lobbying efforts among key U.S. allies in Europe to promote Turkey's EU aspirations. Specifically, the U.S. was involved in three key developments in EU-Turkey relations during the 1990s. First, Washington sought to influence the outcome of the negotiations leading to the signing of a Customs Union Agreement between Brussels and Ankara in December 1995. Initially, the European Parliament did not seem to favor a formal Customs Union with Turkey and most observers expected a close vote. However, this attitude gradually changed and the European Parliament eventually approved the Customs Union agreement. Prior to the vote in the parliament, American officials in Brussels actively lobbied in the European Parliament in support of this major new agreement between the EU and Turkey. The chief U.S. Trade Negotiator, Stuart Eisenstadt, personally headed the U.S. lobbying effort in Strasbourg. Clearly, Washington's campaign played an important role in turning the tide in favor of the outcome desired by Turkey.

Second, the U.S. played a similarly critical role in the outcome of the EU Council's Helsinki summit in December 1999, which formally recognized Turkey's candidacy for full membership. Washington had strongly disapproved the EU's decision in Luxembourg two years earlier, which excluded Turkey from the list of formal candidates for eventual membership. In 1999, the Clinton administration exerted considerable pressure through both formal and informal channels, including telephone calls by President Clinton to European leaders, for a reversal of that decision. Although other developments, including the rise to power of the Social Democrats in Germany and the end of Greece's opposition to Turkey's membership were also important, intensive pressures by high-ranking Clinton administration officials on their European counterparts figured prominently in the modification of the EU's policy toward Turkey. The official statement released by President Clinton following the EU summit meeting welcomed the EU's decision "with pleasure" and noted that the U.S. has "long supported Turkey's bid to join the EU in 

IN THE EUROPEAN UNION

the belief that this would have lasting benefits not only for Turkey, but also for all EU members and the United States."

Third, prior to the EU summit meeting in Copenhagen in December 12, 2002, the U.S. once again launched a major campaign to advance Turkey's prospects for entry into the EU. When President Bush met the leader of the Justice and Development Party, Tayyip Erdogan, at the White House on December 11, he reaffirmed Washington's support for Turkey and declared that the U.S. "stands side by side with Ankara in its bid to join the European Union." Bush also made several phone calls to European leaders while the U.S. Secretary of State Colin Powell urged his European counterparts to set a date for the start of accession talks for Turkish membership. The American support for Turkey was best reflected in the comments of U.S. Deputy Secretary of State Paul Wolfowitz. Speaking in London at the International Institute for Staregic Studies on December 2, he stated: "The decision on E.U members is, of course, Europe's to make. But history suggests that a European Union that welcomes Turkey will be even stronger, and safer and more richly diverse than today. The alternative, exclusionary choice is surely unthinkable." 3 Unlike in 1995 and 1999, Washington's lobbying campaign in 2002 did not achieve its intended goal, which was to have the EU propose a specific date to Turkey for the beginning of accession talks between Ankara and Brussels. In fact, some Europeans complained about the pressures exerted by U.S. officials and claimed that Washington's pressures on behalf of Turkey would be counterproductive. However, many in Washington discounted this argument and saw it as yet another European "excuse" to undermine the Turkish membership. They also doubted that the EU would have agreed to give Turkey a "date for a date" in December 2004 on the issue of a timetable for accession talks if President Bush and other high-ranking U.S. officials had strongly backed Turkey.

1"Clinton Welcomes Turkey's Acceptance of EU Offer," released by the United States Mission to the European Union, Brussels, Belgium, December 11, 1991 accessed at http://www.useu.be/ISSUES/turk1211.html

2"Bush Throws Weight Behind Turkey Ahead of Key EU Decision," Radio Free Europe, December 12, 2002 accessed at http://www.rferl.org/nca/features/2002/12/11122002184838.asp

3"U.S. Presses Turkey's Case on Europe and Cyprus Issues," The New York Times, December 3, 2002. 
It is important to remember, as Alan Makovsky has suggested, that in its diplomatic initiatives on behalf of Turkey's full membership, the U.S. has not asked its European allies to either change the membership requirements to accommodate Turkey or establish a special case for Turkish membership. American officials have maintained that membership rules are an internal EU matter and the EU has the right to apply these rules. At the same time, however, the U.S. has also asked the EU to offer Turkey equal treatment with the other applicants, leave the "door open for eventual Turkish membership", and reject any religious or cultural criteria as the basis for gaining full membership in the European Union. ${ }^{4}$ Washington's position has been that Turkey should be a full member when it meets all the formal criteria for membership and that it should not be denied entry into the EU for some other reason such as its Islamic identity and traditions. What the U.S has demanded from its European allies is not to alienate Ankara by adopting a rejectionist posture and offer Turkey a date for the start of accession negotiations. Otherwise, Washington has agreed with Brussels that Turkey needs to undertake most of the political reforms demanded by the EU in advance of full membership 5 . Washington has also joined the EU in exerting pressure on Turkey for a settlement of the Cyprus conflict although it has not necessarily considered it as one of the prerequisites for membership.

\section{Differences in American and European Approaches}

The vigorous lobbying effort that was launched by the Bush administration in November and December of 2002 in support of Turkey's long-standing quest for EU membership was widely interpreted in Turkey and in international diplomatic and journalistic circles as a tactical move to enlist Turkey's cooperation in the U.S. military campaign in Iraq against Saddam Hussein's regime. This

\footnotetext{
${ }^{4}$ Alan Makovsky, "Turkey's Faded European Dream," in Conference Report: The Parameters of Partnership: Germany, the U.S., and Turkey, Washington, D.C.: American Institute for Contemporary German Studies, 1998, pp.60-61.

${ }^{5}$ The one major exception has been the issue of capital punishment since it is practiced in the U.S.
} 

IN THE EUROPEAN UNION

argument is based on the view that Washington saw Ankara's cooperation critical for a successful outcome in the war, especially in the context of its desire to open a "Northern Front" by deploying a large military force through Turkey. In addition, the U.S. also counted on Turkish cooperation with respect to basing rights for its fighter planes at Incirlik and logistical support to its troops in Northern Iraq through several other bases in eastern Turkey.

Clearly, the Bush administration's effort to secure Turkey's full cooperation in the war against Iraq played a major role in Washington's intense diplomatic activism on the issue of Turkey's EU membership during the last months in 2002. However, as noted earlier, the U.S. has been a staunch supporter of Turkey's entry into the EU as a full member for more than a decade. American policy on EU-Turkey became one of the main pillars of bilateral cooperation between Washington and Ankara and successive U.S. administrations invested considerable diplomatic energy and capital in lobbying among America's European allies on Turkey's behalf. As one longtime observer of U.S.-Turkish relations notes, "probably in no other internal EU issue has the U.S. been so actively involved and asserted a right" as that concerning Turkish membership. ${ }^{6}$ American policymakers have been outspoken in their support for Turkish membership and in their criticism of the Europeans for failing to admit Turkey into the European Union. For example, Strobe Talbott, who served as U.S. Deputy Secretary of State under the Clinton administration and was one of the closest advisors of President Clinton, declared in a talk in 1998: "Turkey's ties to Europe are irreversible and unbreakable; they are a fact of life, not a privilege that comes with membership in this or that institution...We do not believe that European unity and integration will be fully successful if a key European country is set uniquely alone and apart."7

What accounts for Washington's strong endorsement of Turkey's desire to achieve full integration with the European Union? The protection and enhancement of national interests play a major role in the formulation of foreign policy in all countries, including the U.S. Successive administrations in Washington have backed Turkey's

\footnotetext{
6Alan Makovsky, “Turkey’s Faded European Dream,” p. 60.

${ }^{7}$ Strobe Talbott, "Turgut Ozal Memorial Lecture," at the Washington Institute for Near East Policy, October 14, 1998.
} 
plans to join the EU primarily because of their belief that, by facilitating closer ties between Ankara and Washington, this policy serves U.S. national interests. American policy-makers have traditionally viewed the maintenance of close military and political ties with Turkey critical for U.S. regional interests in the Middle East. Following nearly four decades of close bilateral ties during the Cold War, the U.S.-Turkish alliance weathered the uncertainties of the post-Cold War restructuring of the international system. In the 1990s, Washington and Ankara cooperated on a wide range of regional security problems in the Middle East, the Balkans, and the Caucasus. ${ }^{8}$ In addition, the U.S. supported Turkey's position on the Baku-TiblisiCeyhan pipeline development project, helped Turkey capture PKK's leader Abdullah Öcalan, and played an important role in the stabilization of the Turkish economy in the aftermath of the 2001 economic and financial crisis through its support for a new IMF loan package. Although the two countries also had divergent policies regarding the future of Iraq and potential for the emergence of a Kurdish political entity in Northern Iraq, settlement of the Cyprus problem, and U.S. efforts to isolate Iran, the bilateral relationship nevertheless remained strong throughout the decade. The strong backing that the U.S. provided to Turkey on the issue of Turkey's full membership in the EU was part of this broader American policy to strengthen bilateral ties between the two countries.

There are several other factors that help explain the contrasts between strong American support for Turkey's integration into the EU and the European reluctance to admit Turkey into the EU as a full member. ${ }^{9}$ First, as a global power, the U.S. has been much more

${ }^{8}$ I have discussed these developments in greater detail elsewhere. See Sabri Sayari, "Turkey and the United States: Changing Dynamics of an Enduring Alliance," in Tareq Y. Ismael and Mustafa Aydin (eds.), Turkey's Foreign Policy in the $21^{\text {st }}$ Century, Aldershot, U.K: Ashgate., 2003, 27-40, and "U.S.-Turkish Relations: Issues of Convergence and Divergence," in Mustafa Aydin and Cagri Erhan (eds.), 200 Years of Turkish-American Relations, London: Frank Cass (forthcoming).

${ }^{9}$ See Bruce Kuniholm, "Turkey's Accession to the European Union: Differences in European and US Attitudes and Challenges for Turkey," Turkish Studies (Spring 2001), 25-53, and F. Stephen Larrabee, "U.S. and European Policy Toward Turkey and the Caspian Basin," in Robert D. Blackwill and Michael Sturmer (eds.), Allies Divided: Transatlantic Policies 
cognizant of Turkey's strategic importance than Europe. As one highranking American official has argued "integrating Turkey into the EU should be an important objective of the future strategic cooperation between the United States, Europe, and Turkey."10 Throughout the 1990s, the U.S. has viewed Turkey as a key regional power with the potential to influence the outcome of developments in the Middle East, the Balkans, and the Caucasus. Europe, on the other hand, has never had such a broad strategic vision as the U.S. In the post-Cold War era, European concepts of security have moved beyond the realm of traditional military concerns, to include illegal immigration, refugees and asylum seekers, drug trafficking, and environmental problems. Moreover, even in terms of traditional concepts of security, the European outlook on Turkey has been less favorable than that of the U.S. For example, whereas the U.S. has viewed Turkey's geography an asset to pursue its national interests and objectives in the Middle East, the Europeans have been concerned about expanding the EU's borders to a "dangerous neighborhood" that includes Iran, Iraq and Syria. ${ }^{11}$

Secondly, the U.S. has viewed Turkey's entry into the EU as critical for "anchoring" Turkey firmly to the West and defusing the Huntingtonian notion of a "clash of civilizations." The U.S. policymakers have been concerned that if Turkey were excluded from the $\mathrm{EU}$, it might deviate from its traditional pro-Western orientation and search for new, and from Washington's perspective, undesirable regional alliances. Additionally, from the American perspective, the inclusion of a predominantly Muslim country in the EU would forcefully serve as a bridge between the West and the Islamic world. Although some European countries, notably England, shared this perspective with the U.S., others have been far less concerned about

for the Greater Middle East, Cambridge, Massachusetts: The MIT Press, 1997, 143-173.

${ }^{10}$ Zalmay Khalilzad, "A Strategic Plan for Western-Turkish Relations" in Zalmay Khalilzad, Ian O. Lesser, F. Stephen Larrabee, The Future of Turkish-Western Relations, Santa Monica: RAND, 2000, p. 93.

${ }^{11}$ See Ian O. Lesser, “"Beyond Bridge or Barrier: Turkey's Evolving Security Relations with the West," in Alan Makovsky and Sabri Sayari (eds.), Turkey's New World: Changing Dynamics in Turkish Foreign Policy, Washington, D.C.: The Washington Institute for Near East Policy, 2000, 203-221. 
the possible strategic, political, and cultural consequences of Turkey's exclusion and possible alienation from the European integration project.

Thirdly, there is a fundamental difference between the U.S. and Europe concerning the policy consequences of Turkey's full membership in the EU. The Europeans fear that if Turkey were to become a full member, millions of Turkish citizens would migrate to Europe in search of better wages and living conditions. Given Turkey's population, Europeans are concerned that Turkish entry would lead to a drastic redistribution of votes and seats in key EU councils and assemblies. Moreover, there is significant public opposition to Turkey's full membership in many EU countries and support for Turkish membership does not win many votes for European politicians. By contrast, the U.S. will not have to face these and a host of similar issues that worry the Europeans in case Turkey becomes a full member of the European Union. In other words, the policy of supporting Turkey's bid to gain entry into the EU has been relatively "cost- free" for the U.S. The former American ambassador to Turkey, Morton Abramowitz, suggests that "the only cost to the United States [of supporting Turkey's membership in the EU] was a certain European annoyance, perhaps anger at times." 12

Washington's intensive diplomatic efforts for more than a decade to have the EU admit Turkey as a full member have created strains in transatlantic relations. The Europeans have complained, sometimes bitterly, about what they view as undue American pressure and lobbying. They have argued that the U.S. has no right to interfere in the internal EU affairs. European officials have also criticized the U.S. for not being sensitive about their concerns regarding Turkish membership. Germany has been particularly worried about the potential fallout from the EU's reluctance to admit Turkey on German-American relations. In their visits to Washington, German officials and parliamentarians have sought to explain the German and European concerns about Turkey's membership to American policymakers. To provide a forum for the presentation of German and European views on this issue, the American Institute for

\footnotetext{
${ }^{12}$ See Morton Abramowitz, "The Complexities of American Policy Making on Turkey," in Morton Abramowitz (ed.), Turkey's Transformation and American Policy New York: The Century Foundation, 2000, pp. 179-180.
} 
Contemporary German Studies in Washington, which has close ties with German official and academic circles, has organized a number of conferences to discuss EU-Turkey relations and its impact on the trilateral ties between U.S., Germany, and Turkey.

\section{Prospects for the Future}

In the near future, the U.S. is not likely to abandon its support for the inclusion of Turkey in the European Union. Washington's position on this issue is well established and it has become one of the important anchors of the bilateral ties between Washington and Ankara. However, the U.S. is not likely to pursue the highly visible and activist strategy to promote Turkish membership and invest as much diplomatic energy and capital on this issue as it has done in the past. There are two major reasons for this anticipated change. First, the Turkish parliament's unwillingness to support American troop deployment through Turkey for the war in Iraq has significantly affected U.S.-Turkish relations. Although the bilateral alliance remains, the relationship between Washington and Ankara has received a hard blow as a result of the vote in the Turkish parliament on March 1, 2003. Efforts to repair the relations since that fateful parliamentary vote in Ankara have produced some positive results. However, U.S.-Turkish relations has entered into a new phase and it would be unrealistic to expect Washington to lend Ankara the degree of support that it had done so in previous decades on various important regional and international issues. Barring further deterioration in bilateral ties, Washington is likely to continue its support for Turkey's entry into the E.U. But it is doubtful that the U.S. will make an extra effort and lobby intensively on Turkey's behalf among its principal European allies.

Secondly, as noted earlier, the main objectives of Washington's efforts have been to prevent the EU from closing the door on the possibility of Turkish membership, to formally recognize Turkey's candidacy, and to set a date for the beginning of accession negotiations. The first two of these objectives have been met with the decision regarding the Turkish candidacy at the Helsinki summit. In this respect, the U.S. has made substantial progress toward attaining its main goals regarding its long-time support for Turkey's integration into Europe. Consequently, the U.S. is not likely to exert strong 
pressure on its European allies on the Turkish membership question and risk further problems in transatlantic relations in the aftermath of the war in Iraq, which has already created serious strains between America and several key European countries, such as France and Germany. 